\title{
îे \\ Um exame histórico-filosófico da biologia evolutiva do desenvolvimento
}

\author{
Ana Maria Rogha de Almeida \& Charbel Niño El-Hani<smiles>C#CC(C)CC</smiles>

RESUMO

O desenvolvimento tem papel central na compreensão da evolução dos organismos multicelulares, dado que é o processo que resulta na produção da forma orgânica adulta. Logo, toda inovação morfológica deve ser também o resultado de modificações no desenvolvimento. Entretanto, a biologia do desenvolvimento permaneceu à margem da síntese evolutiva e o desenvolvimento foi tratado por muito tempo como uma caixa preta entre o genótipo e o fenótipo. Somente a partir dos anos 1980, foi dada mais atenção ao papel do desenvolvimento na evolução, resultando daí avanços teóricos e empíricos inesperados. Tais avanços resultaram na emergência de um novo campo de investigação, a biologia evolutiva do desenvolvimento (evo-devo), que vem cumprindo papel importante na construção de uma nova compreensão da evolução das formas orgânicas. Argumentamos que este campo tem papel central em uma "nova síntese evolutiva", atualmente em construção, que está comprometida com um "pluralismo de processos", ou seja, com a ideia de que não somente a seleção natural, mas também diversos outros mecanismos têm papel causal e explicativo na evolução biológica. A partir da discussão de algumas dicotomias clássicas no pensamento evolutivo, principalmente aquelas entre estruturalismo e funcionalismo e entre processos transformacionais e variacionais, buscamos situar a evo-devo no panorama do pensamento evolutivo contemporâneo.

Palavras-chave • Biologia evolutiva do desenvolvimento. Evo-devo. Forma. Função. Estruturalismo. Funcionalismo. Transformacionismo. Variacionismo.

\section{A EVO-DEVO NO GONTEXTO HiSTÓRICO DO PENSAMENTO EVOLUTIVO}

Desde a sua apresentação inicial em $A$ origem das espécies (Darwin, 1859), a teoria darwinista da evolução sofreu diversas modificações. Apesar de tais mudanças, uma série de legados dos trabalhos de Darwin permanece central no pensamento evolutivo até hoje, tais como: (1) os argumentos convincentes sobre a realidade da transformação das espécies ao longo do tempo, ou seja, sobre a ideia de evolução que Darwin reuniu em seu livro; (2) a proposta da seleção natural como mecanismo da mudança evolutiva, cuja autoria ele compartilha com o naturalista Alfred Russel Wallace; e (3) a ideia de ancestralidade comum e, logo, a narrativa da evolução como um processo aberto, contingente, sem meta ou objetivo definido, que se mostrou uma das contribuições de 
Darwin de apreensão mais difícil. É esse último processo que Darwin representava por meio de uma árvore, sem qualquer tronco principal, em franca oposição à ideia de uma grande cadeia dos seres, que, remontando ao pensamento platônico e aristotélico, situava as coisas naturais em uma linha única de progresso, desde as coisas inanimadas mais simples até os animais mais complexos e perfeitos, culminando em nossa espécie.

Após um período de controvérsias na década de 1860, Darwin e seus seguidores conseguiram convencer grande parte dos naturalistas contemporâneos de que diversas características dos seres vivos podem ser explicadas pela transformação das espécies por um processo de descendência com modificação. A partir da década de 187̧o, a ideia de evolução gozou, ao menos na comunidade científica, de grande aceitação. No caso da teoria da seleção natural, contudo, a história foi mais conturbada. Para muitos cientistas do final do século xIx, restavam dúvidas sobre o papel da seleção natural (Bowler, 1983, 2003). Entre as décadas de 1890 e 1920, várias teorias evolucionistas explicitamente antidarwinistas, porque negavam o papel da seleção natural no processo evolutivo, foram populares entre os cientistas. Nesse período, a aceitação da teoria darwinista diminuiu tanto que o historiador da biologia Peter Bowler o denomina "eclipse do darwinismo" (mas cf. Largent, 2009).

O darwinismo ressurgiu das cinzas, entretanto, com a síntese evolutiva dos anos 1930 e 1940, construída a partir de sua fusão com o mendelismo, na esteira de contribuições da genética de populações e dos estudos de naturalistas de campo. Desde a década de 194:0, a teoria sintética da evolução tem sido dominante na biologia evolutiva. Mas, a partir dos anos 1980, ela tem sido também objeto de crescente debate.

Na biologia evolutiva, não são objetos de controvérsia nos dias de hoje (1) a ideia de que os seres vivos evoluem e, além disso, que a evolução ocorre, como dizia Darwin, por descendência com modificação; (2) a tese de que todos os seres vivos são aparentados entre si; (3) o importante papel desempenhado pela seleção natural como mecanismo evolutivo. Quanto a este último aspecto, a seleção natural pode ser considerada um mecanismo microevolutivo altamente corroborado, com base em fontes diversas de evidências (Sepulveda, Meyer \& El-Hani, no prelo). Estudos em populações naturais, por exemplo, documentaram a presença de condições que tornam possível a evolução de características por seleção natural, como variabilidade, herdabilidade e aumento de aptidão do portador dos traços em questão. Isso tornou possível explicar a evolução de uma diversidade de traços por seleção natural (por exemplo, Grant \& Grant, 1995, 2002). Também foram realizados estudos empíricos em que populações naturais ou artificiais foram manipuladas, com os pesquisadores controlando o regime de seleção e comparando o efeito de sua ação com aquele esperado, de acordo com a teoria da seleção natural. Em diversos casos, essa abordagem documentou que as populações 
naturais mudaram de uma maneira que era explicada, de modo plausível e parcimonioso, pela seleção natural (Reznick \& Endler, 1982; Reznick, Bryga \& Endler, 1990; Hendry \& Kinnison, 2001; Reznick \& Ghalambor; 2001; Elena \& Lenski, 2003). Por fim, uma teoria quantitativa consistente foi desenvolvida ao longo do século xx, oferecendo modelos sobre como se dão as mudanças genéticas e fenotípicas esperadas sob seleção natural. Essa teoria sustenta a seleção natural, na medida em que prevê que a ação da seleção, atuando sobre indivíduos variantes em populações, é capaz de explicar grandes mudanças observadas ao longo do tempo.

Os debates contemporâneos se situam, antes, em outros pontos de nossa compreensão sobre evolução, como os que seguem: (1) a seleção natural explica todos os fenômenos evolutivos? Ou outros mecanismos são necessários para a construção de tal explicação, lado a lado com a seleção? (2) as grandes mudanças que vemos na história da vida (que são chamadas de "macroevolução") podem ser explicadas apenas a partir da ação da seleção natural dentro das populações (o que chamamos de "microevolução")? (3) o processo evolutivo é sempre gradual ou ele pode ocorrer, de tempos em tempos, a taxas mais rápidas? Estas são algumas das questões que marcam os debates atuais sobre a teoria sintética, bem como as contribuições trazidas pela compreensão do desenvolvimento.

Para a teoria sintética, a seleção natural constitui um mecanismo suficiente para explicar tanto a micro quanto a macroevolução, sendo necessário apenas o complemento de mecanismos que expliquem a separação de populações e a interrupção do fluxo gênico, para dar conta da origem de novas espécies. Assim, o mesmo mecanismo explicaria: (1) como as frequências gênicas e distribuições de características mudam ao longo das muitas gerações de uma população (microevolução); (2) a origem de adaptações através das mudanças dentro das populações; (3) a divergência de populações descendentes, que se separaram a partir de uma população ancestral, dando origem a novas espécies; e (4) tendo em vista o tempo geológico, toda a diversidade biológica, conforme expressa nos grandes padrões mostrados na árvore da vida (macroevolução).

Nos debates atuais, não se questiona a importância da seleção, lado a lado com a deriva gênica, para a compreensão de mudanças dentro de populações. Tampouco está em questão o papel central da seleção na explicação das adaptações. As controvérsias atuais também enfocam a extensão em que características dos seres vivos são adaptações, girando em torno do adaptacionismo (cf. Gould \& Lewontin, 1979), a ideia de que todas as características dos seres vivos são adaptações e, assim, são explicadas por seleção natural. Como a seleção natural constitui hoje a única alternativa válida para a explicação das adaptações (cf. Rosenberg \& McShea, 2008) e, além disso, as adaptações são hoje definidas de maneira que, por uma questão de definição, devem ser 
explicadas por seleção (cf. Sober, 1993), o debate sobre a extensão em que as características dos organismos são adaptações e o debate sobre o domínio de aplicação da explicação seletiva são equivalentes.

Nas últimas décadas, uma compreensão mais aprimorada das possibilidades e dos limites da seleção natural emergiu (Sepulveda, Meyer \& El-Hani, no prelo). Esse novo modo de entender os mecanismos evolutivos decorreu, em parte, de avanços teóricos e empíricos na compreensão do desenvolvimento, que deram origem à biologia evolutiva do desenvolvimento (também conhecida como evo-devo). A mudança teórica que, para alguns autores - entre os quais, nos incluímos -, vem ocorrendo na biologia evolutiva tem como resultado, de acordo com Gould (2002), uma nova teoria darwinista da evolução (e não alguma teoria antidarwinista), na medida em que preserva o poder causal e explicativo da seleção natural. Nas palavras de alguns pesquisadores do campo da evo-devo, estamos diante da perspectiva de uma síntese expandida (Arthur, 1997) ou mais moderna (Carroll, 2006). Em nosso entendimento, essa nova visão da evolução dos seres vivos está comprometida com duas ideias fundamentais: (1) pluralismo de processos, de acordo com o qual, embora a seleção natural seja um importante mecanismo de mudança evolutiva, outros mecanismos também cumprem papéis importantes na evolução e, portanto, em sua explicação (Meyer \& El-Hani, 2000, 2005); e (2) pluralismo de padrões, segundo o qual a árvore da vida não fornece modelo apropriado para tratar das relações filogenéticas de todos os seres vivos, uma vez que, em alguns domínios, como o das bactérias, a transferência genética horizontal é tão preponderante que resulta num padrão reticulado, e não na série de separações dicotômicas de linhagens que resultaria numa árvore da vida (Doolittle \& Bapteste, 2007). Aqui, nossa atenção estará voltada para o pluralismo de processos.

A biologia evolutiva do desenvolvimento pode ter sua origem traçada até a embriologia comparada do século xIX (Arthur, 2002). Ela constitui uma nova abordagem para a compreensão da evolução da forma orgânica, que enfoca genes que regulam o desenvolvimento e os efeitos de mudanças em seus padrões de expressão sobre a forma dos organismos. Após um período de quase um século em que não se aprendeu muito sobre as bases genéticas do desenvolvimento e, em termos mais gerais, sobre os mecanismos subjacentes a esse processo, a descoberta dos genes homeóticos, em meados dos anos 1980 (Scott \& Weiner, 1984; McGinnis et al., 1984), levou a uma explosão de atividade que resultou, na década seguinte, na construção da evo-devo. Nos últimos vinte anos, o principal foco de pesquisa nesse campo tem sido o estudo comparativo dos padrões espaço-temporais de expressão de genes regulatórios do desenvolvimento.

Antes de prosseguir em nosso exame da evo-devo, devemos esclarecer como as relações entre evolução e desenvolvimento são entendidas no contexto do darwinismo. Afinal, a confusão entre esses dois processos foi um dos principais obstáculos para a 
construção de uma compreensão mais consistente e poderosa da evolução (cf., por exemplo, Bowler, 2003). A diferença crucial aqui é entre um processo transformacional, o desenvolvimento, no qual um ser vivo único sofre uma série de transformações até chegar à forma adulta, e um processo variacional/populacional, a evolução, na qual é a distribuição de características variantes que muda ao longo das diversas gerações de uma população, e não as características de organismos individuais. Outra diferença, não menos importante, é que enquanto o desenvolvimento tem um estado final preferencial, a forma adulta, a evolução não se dirige para qualquer estado preferencial (isto é, ela não é teleológica); ao contrário, tal como retratada na narrativa darwinista, ela é um processo contingente e aberto. Contudo, o fato de que evolução e desenvolvimento são processos com naturezas distintas não deve fazer com que percamos de vista o fato de que tais processos se influenciam mutuamente: a evolução modifica o desenvolvimento (o desenvolvimento evolui!) e o desenvolvimento influencia o curso da evolução, na medida em que, no caso dos organismos multicelulares, ele é o processo responsável pela produção da forma orgânica e, assim, de qualquer inovação morfológica que observemos em tais organismos.

No entanto, na mesma medida em que o desenvolvimento é o processo que produz inovações na forma orgânica, ele também restringe as possibilidades de modificação da mesma. Assim, o desenvolvimento limita as possibilidades de variação das características presentes em uma população e, por conseguinte, a ação da seleção natural na medida em que esta depende da disponibilidade de variação populacional. Essas restrições ocorrem porque o desenvolvimento não é um processo infinitamente plástico, mas um processo muito complexo de produção de forma (morfogênese) a partir de um sistema intricado de interações celulares e moleculares. Trata-se, além disso, de um processo no qual a sincronização e a diferenciação espacial e temporal de eventos são muito importantes, de tal maneira que muitas etapas do processo devem ocorrer em uma sequência específica para que determinada forma orgânica seja construída. A complexidade do desenvolvimento e a concatenação de suas etapas fazem, por sua vez, com que certas inovações morfológicas sejam possíveis e certas sejam impossíveis em determinados organismos. Assim, as mudanças evolutivas são restritas àquelas que podem ocorrer como consequência de mudanças no desenvolvimento, que tornam disponíveis variações na forma orgânica com as quais trabalha, por assim dizer, a seleção natural. Isso pode explicar por que certas variedades de formas vivas não são encontradas, como, por exemplo, mamíferos com seis patas, em vez de quatro: o padrão tetrápode evoluiu há muito tempo na linhagem dos vertebrados e o modo como esses animais se desenvolvem dificulta inovações nesse padrão, cuja via de desenvolvimento foi herdada de ancestrais remotos. O desenvolvimento evolui pelo mesmo processo darwinista que resulta na evolução de outras características. Assim, os organismos her- 
dam o modo como seus ancestrais se desenvolviam e essa herança se desdobra em certas possibilidades e certos limites de inovação morfológica em sua evolução futura.

Quando tratamos de restrições impostas à evolução pelo desenvolvimento, parece, em princípio, que elas somente poderiam explicar por que algumas formas vivas não existem, na medida em que constituem processos que impedem a disponibilidade de certas variações para a triagem pela seleção natural. Mas, assim como ocorreu na história do conceito de seleção natural, que passou de um mecanismo negativo na teologia natural britânica, que apenas explicava a eliminação do menos apto, a um mecanismo positivo, capaz de explicar a origem de adaptações e espécies, pelas mãos de Darwin e Wallace (Gould, 2002), também as restrições passaram de um papel apenas negativo para um papel também positivo na evolução. As restrições impostas pelo desenvolvimento podem mudar tanto a direção quanto a velocidade (ou taxa) dos processos evolutivos.

Quais são os processos que tanto produzem quanto limitam as inovações morfológicas que o desenvolvimento torna disponíveis nas populações? Um dos achados centrais da evo-devo é o de que as diferenças de complexidade e organização corporal dos animais estão relacionadas principalmente a mudanças nos padrões espaciais e temporais de regulação gênica (Carroll, Grenier \& Weatherbee, 2005; Carroll, 2006), e não tanto à evolução dos próprios genes que regulam o desenvolvimento, cujas sequências são, em geral, altamente conservadas. Não podemos perder de vista, contudo, que, apesar dos muitos casos de conservação dos padrões de expressão de tais genes, há também casos em que eles diferem notavelmente entre espécies intimamente aparentadas (cf. Arthur, 2002). A compreensão do desenvolvimento e de como ele evolui depende, pois, do entendimento da regulação gênica, fundamental não apenas para a diferenciação celular, mas também para a morfogênese.

É preciso, contudo, evitar uma interpretação inteiramente reducionista da regulação gênica, na qual o papel dos sistemas celulares e mesmo supracelulares nos processos de regulação que ocorrem no interior das células é transferido para as interações moleculares. Essa transferência chega ao ponto de atribuir-se, como vemos em Carroll (2006), à ação na regulação da expressão gênica e às mudanças nos padrões de expressão subjacentes a inovações morfológicas a sequências de DNA, que são reconhecidas por proteínas ligadas a essa molécula. Mas, se as sequências de DNA não são mais do que sequências reconhecidas por proteínas, não são elas em si mesmas que agem nos processos de regulação, mas as proteínas - e também os RNAs - que as reconhecem. Em última análise, a regulação gênica é um processo que implica a influência de processos que ocorrem acima do nível molecular - processos celulares e supracelulares - sobre processos moleculares, tais como transcrição, processamento de RNA, tradução etc. 
Para uma compreensão adequada dos achados e do corpo teórico da evo-devo, é crucial ir além do DNA-centrismo. Ao enfocar o papel da regulação gênica na produção da inovação morfológica, a evo-devo foi além do genecentrismo. Contudo, é preciso ir além também do DNA-centrismo, reconhecendo a natureza celular e supracelular dos processos de regulação gênica. Não se deve perder de vista, portanto, a natureza global do processo - que é celular, tissular, até mesmo orgânico - enfocando somente os efetores finais do mecanismo regulatório, por exemplo, proteínas que interagem com o DNA, regulando a expressão de certos genes. Afinal, não se trata somente de explicar a interação molecular em si e suas consequências, mas também por que uma dada proteína regulatória está presente em certo tempo e lugar. Ao tentar explicar esse último ponto, nos veremos envolvidos em redes de interações celulares e tissulares. ${ }^{1}$

Uma das descobertas mais surpreendentes da evo-devo foi a de que os genes que regulam o desenvolvimento são extremamente conservados nos animais bilaterais e tal conservação vai além dos genes em si: o modo como os genes e seus produtos interagem é, também, semelhante em organismos morfologicamente muito distintos (Carroll, Grenier \& Weatherbee, 2005; Carroll, 2006; Raff, 1996). Ou seja, nesses animais, embora os sistemas de regulação gênica sofram mudanças, de modo que os organismos se diferenciam em sua morfologia, há também muitas semelhanças entre seus sistemas genéticos no que diz respeito à regulação do desenvolvimento. Esses avanços forçaram a biologia a rever inteiramente suas ideias sobre a evolução das formas. Em contraste com a intuição anteriormente prevalente de que organismos estruturalmente mais complexos deveriam ter mais genes envolvidos na regulação de seu desenvolvimento, não parece haver relação simples entre similaridade genética e similaridade morfológica: animais bastante distintos em termos morfológicos, como uma mosca e um humano, ou um bivalve e um peixe, utilizam - para usar uma metáfora proposta por Carroll (2006) - a mesma “caixa de ferramentas" genéticas para o desen-

\footnotetext{
1 A pertinência desta interpretação é reforçada por análises da organização funcional de redes protéicas em sistemas celulares. Gavin e colaboradores (2002), por exemplo, mostraram que os complexos protéicos em leveduras estão, em sua maioria, associados uns com os outros, direta ou indiretamente, através de proteínas compartilhadas. Como um dos pesquisadores envolvidos neste estudo disse a Sampedro (2002, p. 61), é como se "toda a célula fosse uma máquina única”. Mais da metade dos complexos protéicos analisados por Gavin e colaboradores está envolvida em processos que influenciam a regulação gênica. Além disso, há evidências de que os sistemas celulares envolvidos na transcrição e no processamento e transporte de RNA não constituem um sistema linear de processos, mas uma rede complexa e extensamente acoplada, na qual sinais regulatórios circulam de maneira não-linear, dando origem a várias alças de retroalimentação (Maniatis \& Reed, 2002; Kornblihtt et al., 2004). No mínimo, é esta estrutura em rede que está, em última análise, implicada na regulação da expressão gênica, e não somente regiões regulatórias no DNA, ou mesmo proteínas, RNAs ou genes isolados. As mudanças nos padrões de expressão dos genes são, na verdade, mudanças na estrutura de relações dos sistemas genéticos, sendo estas dependentes, por sua vez, de sistemas supracelulares.
} 
volvimento. Esta é uma metáfora interessante, porque rompe com uma visão do desenvolvimento na qual toda a ação é atribuída a genes ou ao DNA. Afinal, se os genes que regulam o desenvolvimento são ferramentas, eles devem ser usados por algum sistema que manipule tais ferramentas. Como argumentamos acima, podemos atribuir ao sistema celular o papel de manipular a "caixa de ferramentas" genéticas.

François Jacob (1977) escreveu, em um artigo que teve grande influência sobre o pensamento evolutivo das últimas décadas, que a evolução não consiste em um processo de engenharia, mas de bricolagem. Não se trata de algum "planejamento inteligente", como insistem alguns autores contemporâneos, em nosso entendimento de maneira inteiramente equivocada, mas de um reaproveitamento oportunista de estruturas preexistentes, que, uma vez modificadas, adquirem novas funcionalidades para os organismos. Os genes que regulam o desenvolvimento têm sido repetidamente reaproveitados ao longo da evolução, em um caso notável de bricolagem, sendo expressos nos embriões em tempos e lugares distintos, o que muda a sincronização ou diferenciação espacial e temporal dos processos de desenvolvimento, bem como regula a atividade de genes distintos em diferentes espécies.

A "caixa deferramentas" para o desenvolvimento inclui principalmente genes que codificam fatores de transcrição e moléculas de sinalização celular, que mediam a comunicação entre as células. O modo de operação da "caixa de ferramentas" é caracterizado por cascatas de eventos regulatórios, nos quais genes regulatórios ativados em um momento $t$ do desenvolvimento foram, eles próprios, ativados por outros genes regulatórios em $t-1$ e, por sua vez, ativarão ou reprimirão genes - muitas vezes também regulatórios $-\mathrm{em} t+1$. Estas cascatas terminam em genes que têm papéis importantes na morfogênese, de modo que a geração da forma orgânica ocorre de modo altamente regulado. Nesse processo, a posição na qual ocorrem certos eventos dentro do embrião cumpre papel central, podendo o desenvolvimento ser entendido, inclusive, como a transformação de posição em forma, como argumentou Edelman (1988). Podemos tratar a posição (não somente espacial, mas também temporal) em que eventos desenvolvimentais ocorrem como um tipo de informação epigenética, a informação posicional.

Essa informação posicional vai sendo refinada ao longo das cascatas de eventos de regulação de genes envolvidos no desenvolvimento e remonta, em última análise, à informação posicional encontrada no óvulo, na forma de moléculas distribuídas assimetricamente. Tais moléculas são RNAs transcritos a partir de genes de efeito materno, distribuídos em gradientes ao longo do citoplasma do óvulo, de tal maneira que, com as primeiras divisões zigóticas, cada célula do embrião adquire uma composição bioquímica distinta. Esses transcritos codificam fatores de transcrição e, uma vez traduzidos nos primeiros eventos do desenvolvimento embrionário, regulam padrões de expressão de genes regulatórios do desenvolvimento que serão importantes para pro- 
cessos centrais no desenvolvimento do embrião, como o estabelecimento dos eixos anteroposterior e dorsoventral (Carroll, Grenier \& Weatherbee, 2005). Esse é um caso de herança materna e epigenética, uma vez que o zigoto retém o citoplasma do óvulo (sem qualquer contribuição citoplasmática do espermatozóide) e, portanto, também sua informação posicional, estabelecida no processo de ovogênese.

Os primeiros passos do desenvolvimento dependem de modo crucial dessa informação posicional. De fato, o genoma do zigoto não é expresso durante esses primeiros passos, que constituem, assim, um legado desenvolvimental das mães. Os produtos gênicos maternos regulam o desenvolvimento inicial do embrião até a transição maternal-zigótica, quando a transcrição embrionária se inicia e muitos RNAs maternos são degradados (Oh et al., 2000; Schier, 2007). Em camundongos, por exemplo, a completa ativação do genoma embrionário só ocorrerá por volta de 35 horas após a fertilização (Wassarman et al., 1979; Schultz, 1993), ou seja, o período de inatividade transcricional do embrião pode durar quase dois dias. Nesse período, ocorre um evento fundamental no desenvolvimento inicial dos mamíferos, a reprogramação epigenética do genoma, principalmente através de metilação do DNA e modificação de histonas (Santos \& Dean, 2004), de modo a constituir o genoma ativo do embrião, agora totipotente.

Em seus argumentos a favor do núcleo como o único portador do material hereditário, Weismann (1983 [1893], p. 22) argumentou que, se o citoplasma também contribuísse para a hereditariedade, a fêmea contribuiria mais para a formação do zigoto do que o macho. Portanto, concluiu ele, o citoplasma não deve ter um papel na herança, porque "nós sabemos que a capacidade do pai para a transmissão é tão grande quanto a da mãe". Hoje, sabemos que as fêmeas de fato transmitem mais informação para seus filhos do que os pais, porque legam não somente informação nuclear, mas também citoplasmática, na forma de informação posicional.

A informação posicional tem um papel fundamental na especificação gradual, passo a passo, dos futuros celulares ao longo do desenvolvimento. Desde a primeira metade do século $\mathrm{xx}$, embriologistas têm investigado esse processo por meio de "mapas de destino" (fate maps). Preferimos falar, contudo, em “futuro", e não "destino", porque este último termo tem conotações metafóricas deterministas que, em nosso entendimento, não são compatíveis com a compreensão atual sobre o desenvolvimento. O termo "futuro", por sua vez, deixa em aberto a possibilidade da contingência. As células tenderão a seguir por certas trajetórias desenvolvimentais, mas mudanças no percurso podem ocorrer, sendo esta a origem de muitas inovações morfológicas.

À medida que o desenvolvimento prossegue, células com posicionamentos distintos no embrião terão seus futuros cada vez mais especificados (sempre deixando espaço para a contingência). Quando uma célula se envolve na efetiva produção de uma 


\section{Mapas do destino}
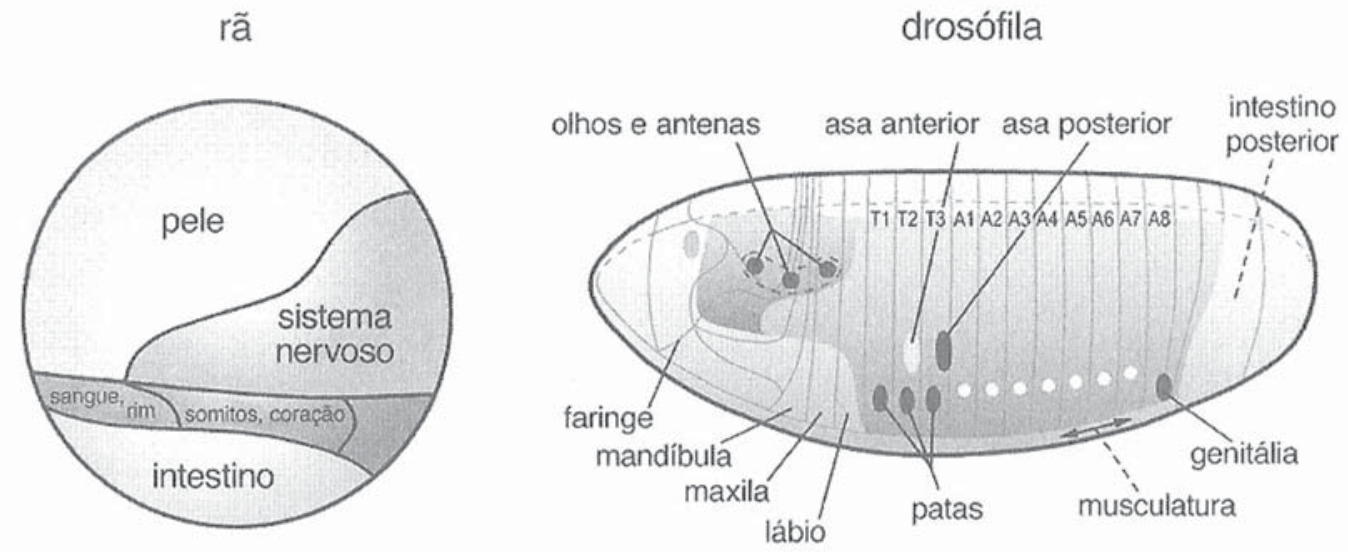

Figura 1. Mapas do destino de embriões de rã e drosófila nos primeiros estágios de desenvolvimento.

estrutura, muitos passos anteriores de especificação do futuro celular ocorreram. Cada um desses passos corresponde à produção de determinado padrão de expressão gênica, a depender da posição ocupada pela célula no embrião (o que mostra uma influência regulatória descendente, isto é, todo-parte, importante no desenvolvimento). Esses padrões de expressão são estabelecidos no contexto das cascatas de regulação do desenvolvimento discutidas acima. Desse modo, à medida que o embrião vai sendo dividido em compartimentos ou módulos cada vez mais finos, as células que se encontram nesses módulos vão tendo seus futuros cada vez mais delimitados, até o ponto em que começam a participar da formação de estruturas orgânicas em posições finamente especificadas.

Segue disso tudo que alterações na informação posicional, decorrentes de mudanças nas sequências de DNA reconhecidas por moléculas que regulam genes desenvolvimentais, podem levar a mudanças radicais na formação das estruturas orgânicas. São esses processos que explicam o que William Bateson, na virada do século xix para o xx, chamou de homeose, ou seja, mudanças discretas e completas de um órgão a outro (cf. Bateson, 1894). Tratava-se de mudanças que resultavam em um novo órgão de maneira muito rápida, e não da maneira gradual típica da ação da seleção natural. Em 1915, o geneticista Calvin Bridges descobriu o primeiro mutante exibindo homeose (isto é, homeótico): uma drosófila mutante que apresentava quatro asas, em vez das duas asas que são uma característica diagnóstica dos dípteros (Bridges \& Morgan, 1923). Esse tipo de inovação morfológica gera animais que são muito diferentes da morfologia 
tipicamente encontrada em uma população, ou seja, se comparados com a média morfológica da população, podemos dizer que são "monstros”. Mas poderiam alguns desses monstros ter "esperança" de um futuro melhor, como propôs Richard Goldschmidt em 1940? Enquanto esse geneticista não tinha, treze anos antes da construção do modelo da dupla hélice por Watson e Crick, qualquer chance de propor um mecanismo que permitisse explicar a geração e a esperança de tais monstros, hoje nossa compreensão do desenvolvimento e, em particular, de sua regulação permite explicar como tais alterações notáveis da morfologia dos organismos podem ocorrer. É preciso explicar, contudo, em quais situações ecológicas esses organismos muito diferentes da média morfológica de suas populações podem levar vantagem, relativamente a outros organismos, tendo mais sucesso na obtenção de recursos e, assim, na sobrevivência e reprodução. Não temos como tratar desse assunto em detalhes no presente artigo, mas gostaríamos somente de apontar que ele mostra como a evo-devo deve evoluir naturalmente para uma eco-evo-devo.

De acordo com uma compreensão que vem se tornando dominante na biologia evolutiva atual, não devemos recorrer apenas à seleção natural para explicar toda a evolução, apesar de ser um mecanismo que continua cumprindo papel fundamental no pensamento evolutivo. Hoje, a biologia evolutiva é mais pluralista, recorrendo tanto à seleção natural como a outros mecanismos, como as restrições ao processo evolutivo, para explicar a origem de características e espécies de seres vivos. A explicação da evolução de um grupo de organismos com frequência combina processos populacionais graduais, nos quais características vão tendo suas distribuições modificadas ao longo das gerações de uma população por seleção natural, e processos mais rápidos, nos quais alterações no desenvolvimento, em particular na sua regulação, podem ter papel importante. No caso dessas alterações do desenvolvimento, temos mudanças da morfologia dos organismos que não ocorrem de modo tão gradual, podendo, inclusive, envolver homeose.

Com a evo-devo, temos uma explicação mais completa e consistente sobre a origem das formas sobre as quais a seleção natural pode atuar. Dessa forma, fortalecemos a visão darwinista da evolução, ao construir uma teoria mais sólida sobre a origem da diversidade das formas orgânicas. Mas será esse realmente o caso? Afinal, a ênfase sobre o desenvolvimento esteve relacionada a várias tradições de pesquisa na biologia evolutiva que se opuseram ao darwinismo. Não poderia ser também o caso da evo-devo, que se constituiria, assim, não em uma parceira, mas uma teoria alternativa, uma adversária das teorias darwinistas? Para examinar a questão, discutiremos algumas dicotomias utilizadas por diferentes autores para caracterizar a oposição entre o darwinismo e outras visões sobre a evolução, cujas lentes tipicamente recaíam sobre o papel do desenvolvimento. Essa será nossa estratégia para ilustrar como um olhar informado 
pela história e filosofia da ciência pode ajudar na compreensão de conteúdos específicos das ciências biológicas. Sem tal olhar, torna-se muito difícil compreender de maneira apropriada o que está acontecendo atualmente no campo da biologia evolutiva.

\section{O DARWINISMO, SUAS ALTERNATIVAS}

\section{E AS RELAÇÕES GOM A BIOLOGIA EVOLUTIVA DO DESENVOLVIMENTO}

Há consenso entre os historiadores e os filósofos da biologia sobre o fato de que a embriologia e áreas correlatas, como a anatomia comparada e a morfologia, campos de pesquisa extremamente férteis antes e logo após a publicação de $A$ origem das espécies, foram deixadas de fora da síntese evolutiva moderna das décadas de 1930-194.0, apesar de o desenvolvimento ter desempenhado anteriormente importante papel no pensamento evolutivo (Mayr \& Provine, 1980; Gould, 2002; Hull, 2002; Arthur, 2002; Bowler, 2003; Amundson, 2005). No entanto, parece não existir igual consenso a respeito das causas de tal fato.

Para muitos autores (como Amundson 2005, por exemplo), a síntese evolutiva produziu uma nova maneira de entender a hereditariedade. Com a formulação da teoria cromossômica da herança, a hereditariedade foi separada dos processos de desenvolvimento embriológico. A fusão da teoria cromossômica da herança com os modelos matemáticos da genética de populações teria tornado, portanto, o estudo do desenvolvimento obsoleto para os construtores da síntese (cf. Amundson, 2005, p. 159). Afinal, se o desenvolvimento não era relevante para o estudo da herança, não havia razão para justificar a inclusão da embriologia na síntese evolutiva. A inclusão do mendelismo, consolidado na forma da teoria cromossômica, parecia suficiente.

Apenas após a publicação do trabalho seminal de Stephen Jay Gould a respeito das relações entre ontogenia e filogenia e, em particular, sobre o papel da heterocronia (mudanças evolutivas causadas por alterações no ritmo do desenvolvimento) no surgimento de novas formas (cf. Gould, 1977), foi dada mais atenção ao papel do desenvolvimento na evolução. A separação teórica entre os estudos da forma e os estudos evolutivos levou muitos autores a postularem a ideia de uma dicotomia entre estruturalismo e funcionalismo na história do pensamento biológico (Ospovat, 1981; Gould, 2002; Bowler, 2003; Amundson, 2005). Segundo Amundson (2005), estruturalistas e funcionalistas estão comprometidos tanto com objetivos explicativos quanto com mecanismos causais distintos. Essas diferenças decorrem de seus focos sobre as explicações da forma e da função, respectivamente.

De um lado, os estruturalistas sustentam que, como as mudanças adaptativas são modificações da forma e a forma de um organismo é produto de seu desenvolvimento, 
o estudo da evolução biológica deveria passar, necessariamente, pelo estudo dos processos de modificação do desenvolvimento embrionário dos organismos, ou seja, pela produção de inovações morfológicas por meio de tais processos. A origem de novas espécies estaria, pois, necessariamente relacionada à origem de novas formas. Teorias estruturalistas estão geralmente comprometidas com visões do processo evolutivo que enfatizam tendências lineares de transformação, em franca oposição à visão divergente, aberta, contingente, não teleológica da teoria darwinista.

Já para os funcionalistas, como Darwin, a primazia causal é atribuída à função das estruturas e às necessidades adaptativas dos organismos, enquanto os padrões de organização estrutural são considerados subprodutos da função. Segundo os funcionalistas, a seleção natural atua sobre as características dos organismos adultos, independentemente das suas origens ontogenéticas. A adaptação carrega a carga explicativa no pensamento evolutivo, o que implica o poder explicativo pleno ou principal da seleção natural, como causa da adaptação.

A dicotomia forma-função pode ser encontrada até mesmo em A origem das espécies, na qual Darwin afirma: "É geralmente admitido que todos os seres orgânicos foram formados com base em duas grandes leis - unidade do tipo e condições da existência" (Darwin, 1859, p. 206). No entanto, Darwin acreditava que a unidade de tipo (e, portanto, a forma dos organismos) poderia ser explicada pela unidade de descendência e, para ele, a lei das condições da existência era superior e englobaria a unidade de tipo, posto que esta última nada seria além do resultado da herança de adaptações prévias dos organismos (p. 206). Segundo Amundson (2005), a batalha sobre a primazia da forma ou da função não chega ao fim com a posição darwiniana: apesar de Darwin argumentar que as estruturas dos organismos atuais foram produzidas mediante adaptação prévia dessas estruturas em organismos ancestrais, os estruturalistas argumentam que a mudança adaptativa ocorreu em uma estrutura que preexistia à mudança em si. Assim, temos um problema do tipo quem veio primeiro: o ovo ou a galinha?

Para Caponi (2005), o ponto central para a compreensão das diferenças entre o darwinismo e as teorias alternativas não reside na dicotomia estruturalismo-funcionalismo, ou, de sua parte, na dicotomia destacada por Mayr (1998 [1982]) entre pensamento tipológico e populacional, e sim na oposição entre transformacionismo e variacionismo. O programa darwinista sempre teve que enfrentar uma série de teorias alternativas que, na visão de Caponi, compartilham um conjunto de pressupostos fundamentais, buscando articular uma explicação transformacional da evolução, alternativa à explicação de tipo variacional ou selecional proposta no darwinismo. Caponi (2006) apresenta uma interpretação alternativa às interpretações desses autores para o cenário que antecedeu a publicação de $A$ origem das espécies. 
Um ponto importante dos argumentos de Caponi - com o qual concordamos - é o de que não faz sentido identificar um adaptacionismo pré-darwinista, como fazem Amundson (1996) e Gould (2002). Para Caponi (2006), o funcionalismo dos naturalistas pré-darwinianos, a exemplo de Cuvier, não implica uma abordagem adaptacionista da forma, uma vez que as características morfológicas e comportamentais não são explicadas em termos dos desafios ambientais enfrentados pelos organismos, mas em termos de necessidades impostas pelas leis de coexistência entre as partes em um todo funcional, que regem a fisiologia dos organismos. Caponi $(2005,2006)$ argumenta que a grande ruptura entre o darwinismo e a biologia precedente esteve centrada na oposição entre a perspectiva fisiológica, que dirigira todo o campo das ciências da vida desde Aristóteles até Cuvier, e a perspectiva populacional que emergiu com a explicação darwiniana dos processos evolutivos. É com base nesse argumento que ele defende a oposição entre as visões transformacionais e variacionais como caminho esclarecedor para a compreensão da história da biologia evolutiva.

Nossa visão a respeito é a de que cada uma dessas dicotomias ilumina aspectos importantes do pensamento darwinista e de formas alternativas de conceber a evolução, e, no caso particular da oposição entre estruturalismo e funcionalismo, de um requisito fundamental na construção atual de uma compreensão da evolução pautada por um pluralismo de processos, na busca de uma síntese entre forma e função. Em vez de defender uma dessas oposições em relação às demais, como a mais esclarecedora da história do pensamento evolutivo, consideramos que, a depender do foco de cada estudo, cada uma delas pode ser mobilizada com proveito. Nossa única ressalva será que, de fato, não é possível identificar uma visão adaptacionista antes do surgimento do darwinismo, sendo melhor tratar nesse período de visões funcionalistas, pura e simplesmente.

Uma das consequências de a embriologia não ter desempenhado papel significativo na síntese evolutiva moderna foi a quase exclusão do pensamento estruturalista, com o largo predomínio da visão funcionalista. No contexto desta última visão, os fenômenos evolutivos passaram a ser entendidos como resultantes da modificação de frequências gênicas nas populações, decorrentes das pressões seletivas do meio. Nas últimas duas décadas, contudo, a biologia assistiu à ascensão de um novo campo de pesquisa, a biologia evolutiva do desenvolvimento, ou evo-devo, que não somente enfoca os processos desenvolvimentais, mas também tem claro viés estruturalista (ver, por exemplo, Arthur, 2002). Desse modo, a emergência do novo campo leva à retomada de velhas questões, reacendendo os debates em torno das dicotomias mencionadas acima, sobretudo daquela entre estruturalismo e funcionalismo.

Com a integração dos métodos da biologia molecular, a evo-devo tem sido capaz de promover um entendimento mais completo das grandes transições evolutivas, bem como da construção dos planos corporais e do surgimento de novidades evolutivas 
(Wagner, 2007). O futuro desse campo ainda é incerto, assim como é incerto o futuro de uma nova síntese evolutiva. Como contemporâneos de tais processos históricos de mudança do pensamento evolutivo, não podemos ter uma visão clara de suas tendências e de seus desdobramentos. No entanto, caso ocorra a construção de uma nova síntese, a evo-devo provavelmente será um dos elementos centrais na elaboração de uma teoria capaz de fornecer narrativas e modelos de mecanismos conectando processos moleculares, como os de evolução genômica, processos desenvolvimentais, que levam do zigoto ao fenótipo do organismo multicelular adulto, funções de estruturas fenotípicas, processos da genética de populações envolvidos na mudança evolutiva, e processos ecológicos que estabelecem regimes seletivos. De fato, no campo da evo-devo, diversos pesquisadores vêm mostrando como o desenvolvimento está intimamente conectado à evolução. Contudo, estamos ainda muito longe de uma síntese que conecte todos os aspectos acima mencionados, de modo que campos como a evo-devo e as investigações sobre a evolução genômica ainda mostram poucos sinais de diálogo.

Como afirma Caponi:

O surgimento e a consolidação desse novo capítulo da biologia evolutiva, que é a biologia evolutiva do desenvolvimento, também chamada de evo-devo, nos obriga a reconsiderar e a rediscutir alguns aspectos centrais dessa concepção da biologia evolutiva que a filosofia da biologia construiu à luz da nova síntese instaurada na década de 194,0 (2007, p. 199).

Precisamos perguntar em que sentido a evo-devo contribui para uma reestruturação da biologia evolutiva que vá além do arcabouço teórico da síntese moderna. Assim, precisamos não apenas atribuir um papel causal aos processos do desenvolvimento, mas também situá-los frente aos agentes causais considerados na síntese moderna. E, ainda mais do que isso, caso concordemos que a evo-devo de fato contribui para um melhor entendimento do processo evolutivo, por apresentar novos agentes causais na produção da diversidade biológica, precisamos buscar maneiras de incluir esse conhecimento no ensino da evolução, inicialmente, na formação de novos biólogos e professores de biologia.

Em relação à questão que colocamos acima, a saber, se a evo-devo, com sua ênfase estruturalista, é uma parceira do darwinismo, ou uma teoria alternativa a ele, com sua ênfase funcionalista, nossa visão é de que esse campo de investigação cria novas possibilidades de síntese entre as visões estruturalistas e funcionalistas, propõe novas maneiras de relacionar estrutura e função em nossa compreensão da evolução, no contexto de uma teoria variacional. Ela não sucumbe, assim, à tentação de derivar da ênfase no papel da estrutura biológica na evolução uma visão transformacional do processo 
evolutivo, que termina por confundir evolução e desenvolvimento. Dessa maneira, ela mantém suas credenciais darwinistas, apoiando-se no pensamento populacional e preservando o importante papel causal e explicativo da seleção natural.

Na próxima seção, buscaremos expor, através de um exemplo ilustrativo, como a evo-devo pode contribuir para a construção de uma abordagem que compatibilize as perspectivas estruturalistas e funcionalistas em um mesmo quadro explicativo dos fenômenos evolutivos.

\section{UM EXEMPLO ILUSTRATIVO DE GOMO A EVO-DEVO GONTRIBUI PARA A EXPLICAÇÃO DA EVOLUÇÃO DA FORMA ORGÂNICA}

Nesta seção, utilizaremos a evolução dos cetáceos como um estudo de caso sobre a contribuição do desenvolvimento para a explicação da evolução da forma orgânica. Em particular, enfocaremos como a evolução por seleção natural e alterações da forma devidas ao desenvolvimento combinam-se em uma narrativa evolutiva que também tem em conta os mecanismos envolvidos. Assim, veremos também como visões funcionalistas e estruturalistas da evolução podem encontrar, na mudança teórica que parece estar em curso na biologia evolutiva, um acordo maior do que tiveram no passado. Ao menos, esta é uma promessa que podemos vislumbrar no presente.

O plano corporal dos cetáceos apresenta inúmeras modificações em relação ao padrão mais usual nos mamíferos, que tiveram papel central em sua especialização para a vida aquática. Por exemplo, modificações cranianas resultaram no posicionamento dorsal das narinas e alterações da porção caudal da coluna vertebral resultaram no desenvolvimento do tecido cartilaginoso que deu origem à nadadeira caudal típica dos cetáceos. Ainda mais notórias são as mudanças sofridas pelos membros. Os membros anteriores tornaram-se nadadeiras, com os dedos individuais não podendo ser distinguidos, graças ao surgimento de membranas interdigitais, enquanto os membros posteriores apresentam variados graus de redução nos diferentes grupos de cetáceos. Nos cetáceos modernos, esses membros estão ausentes, mas alguns elementos ósseos permanecem dentro de seu corpo. Muito raramente, nascem cetáceos modernos com pequenos membros traseiros. Além disso, o pescoço dos cetáceos é curto e seu corpo é hidrodinâmico. Apesar da variação em seu tamanho corporal, todos os cetáceos modernos são relativamente similares em sua forma, apresentando estes caracteres derivados.

Recentemente, Thewissen e colaboradores (2006) elaboraram uma interessante hipótese para a evolução dos membros posteriores dos cetáceos, ponto fundamental na evolução do plano corporal do grupo. Com base em dados paleontológicos e de biologia do desenvolvimento, os autores propõem uma filogenia para o grupo que está de 
acordo com as narrativas anteriores sobre sua evolução, mas traz novidades muito importantes no que diz respeito aos mecanismos envolvidos. A explicação que apresentam para a ausência de membros posteriores nos cetáceos é apoiada por evidências paleontológicas, funcionais e do desenvolvimento.

A redução dos membros posteriores está bem documentada por evidências paleontológicas, sendo funcionalmente relacionada a diferentes padrões de locomoção (Thewissen \& Fish, 1997). Os cetáceos se originaram há cerca de 50 milhões de anos, no Eoceno (ca. 54-34, milhões de anos atrás), e seus membros traseiros retiveram o padrão de quatro dedos e três falanges pelos 9 milhões de anos seguintes. Os ancestrais dos cetáceos eram artiodáctilos terrestres, similares a pequenos cervos. Entre os artiodáctilos viventes, os hipopótamos são os parentes mais próximos dos cetáceos. No entanto, os artiodáctilos mais proximamente aparentados desses animais não se encontram na fauna atual. Trata-se da família Raoellidae, um clado extinto, restrito ao Eoceno inferior e médio, aproximadamente entre 55 e 45 milhões de anos atrás (ver a figura 2). Entre esses animais, evidências convincentes indicam que Indohyus é o parente mais próximo dos cetáceos, com base no conhecimento que temos do registro fóssil dos Raoellidae (ver a figura 3). Há várias linhas de evidências que indicam que

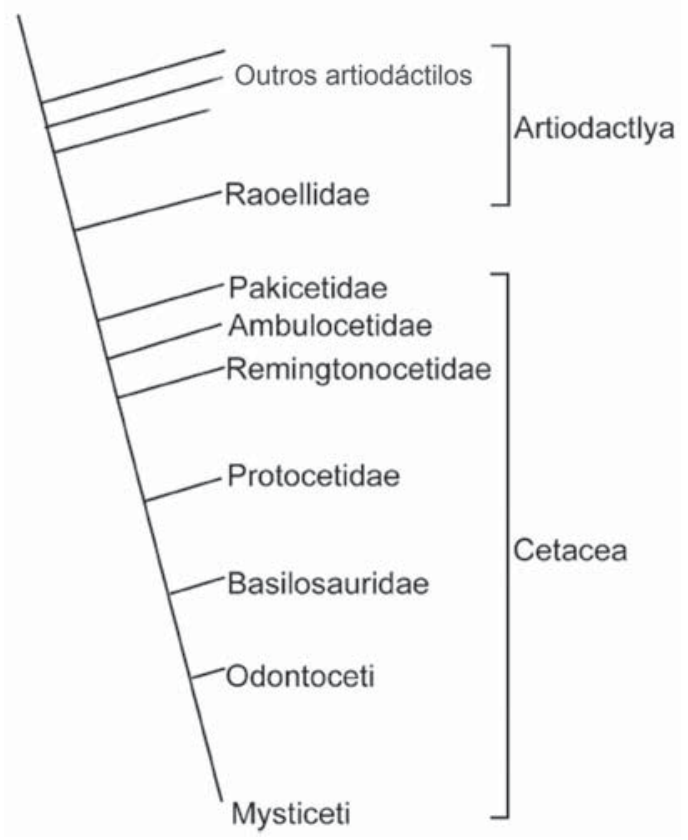

Figura 2. Filogenia mostrando a relação dos cetáceos e de seus parentes terrestres, artiodáctilos da família Raoellidae. 
Indohyus era um animal aquático que poderia passar grande parte de sua vida na água. Portanto, os cetáceos podem ter se originado de ancestrais que já eram aquáticos (Thewissen et al., 2007, 2009). ${ }^{2}$

Os primeiros cetáceos foram os Pakicetidae (ver a figura 4). Trata-se de uma família de animais anfíbios, com coxas e panturrilhas relativamente reduzidas e grandes pés utilizados para a natação, que apresentam uma série de características anatômicas compartilhadas com outros cetáceos, o que torna bastante convincente sua classificação entre os Cetacea. Os primeiros esqueletos desses cetáceos só foram descobertos em 2001, apenas em alguns sítios no Paquistão e na Índia, datando de aproximadamente 50 milhões de anos atrás, no Eoceno médio. Três gêneros de Pakicetidae são conhecidos, todos fósseis: Ichthyolestes, Pakicetus e Nalacetus. Esses animais não eram semelhantes aos cetáceos modernos, sendo mais parecidos com lobos dotados de grandes narizes e caudas. Evidências geológicas indicam que eles viviam em lagoas rasas de água doce, em um clima quente e seco. Várias evidências, como a posição dos olhos, no topo do crânio dos esqueletos encontrados, sugerem que esses animais não eram predadores terrestres, mas animais que viviam na água, olhando para objetos emersos. A morfologia e os desgastes dos dentes indicam uma nutrição baseada em peixes. A partir de dados anatômicos, podemos avaliar quão notável foi a transição da família Raoellidae para a família Pakicetidae e, logo, de artiodáctilos para cetáceos. Muitas características do crânio e das estruturas relacionadas à alimentação mudaram nessa transição, não obstante as várias semelhanças entre a anatomia de espécies como Indohyus e Ichthyolestes ou Pakicetus. Além disso, embora os Pakicetidae tenham herdado o estilo de vida aquático de seus ancestrais comuns com os Raoellidae, houve mudanças ecológicas importantes na vida desses animais, como mostra a anatomia de estruturas envolvidas na alimentação como, por exemplo, os dentes (Thewissen et al., 2009).

Os Ambulocetidae foram os primeiros cetáceos marinhos (ver a figura 4). Esta é uma família de animais que também são anfíbios. Encontrados apenas na Índia e no Paquistão, os fósseis de Ambulocetidae datam de cerca de 49 milhões de anos, no Eoceno médio. Os espécimes conhecidos do gênero Ambulocetus, por exemplo, são muito maiores do que qualquer Pakicetidae, mais ou menos com o tamanho de um grande macho de leão marinho. As patas eram curtas e poderosas, com os pés sendo muito maiores do que as mãos. Dada a robustez das vértebras caudais, é provável que esses

2 Atualmente, a origem dos cetáceos é um dos exemplos de macroevolução mais bem documentados no registro fóssil (Thewissen et al., 2009). Desde os dias de Darwin, já se sabia que esses animais tinham ancestrais terrestres. No entanto, não foi senão no começo dos anos 1990 que os primeiros fósseis que registravam a passagem desse grupo da terra para a água foram encontrados, principalmente na Índia e no Paquistão. A partir da descoberta de Indohyus, tornou-se mais claro que a transição da terra para a água poderia já ter ocorrido antes mesmo de o primeiro cetáceo ter surgido, ou seja, dentro do clado dos Raoellidae . 
Figura 3. Esqueleto do artiodáctilo Indohyus, da família Raoellidae, reconstruído a partir de ossos de vários indivíduos.

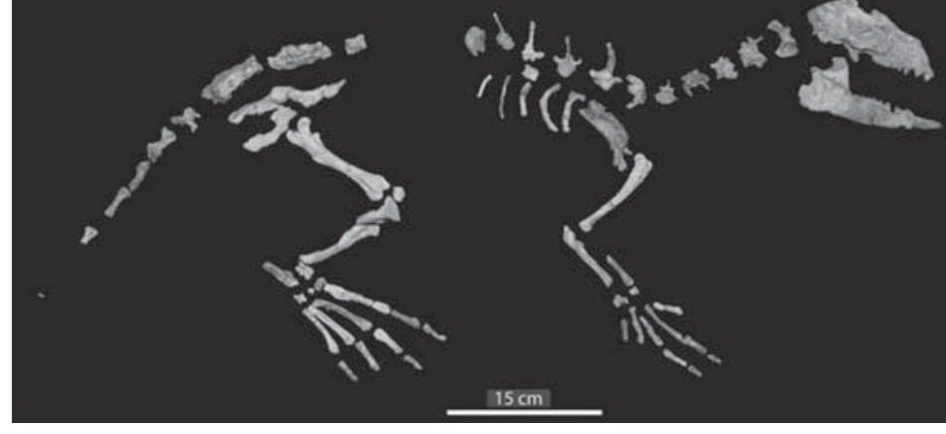

animais possuíssem caudas musculosas. A presença de uma pélvis grande indica que esse animal podia utilizar seus membros para andar no meio terrestre. As evidências disponíveis sugerem que Ambulocetus era um predador de vida aquática, que emboscava suas presas, lembrando um crocodilo, tanto em seu comportamento de caça, quanto em sua morfologia externa. As proporções dos membros de Ambulocetus são similares àquelas observadas em lontras de água doce e é provável que aquele cetáceo nadasse como as lontras, usando suas patas traseiras e cauda para propulsão na água. Embora os fósseis de Ambulocetus tenham sido encontrados em rochas que se formam em mares rasos, evidências isotópicas sugerem que se tratava de um animal estuarino (Thewissen et al., 2009).

Tanto nos Pakicetidae, quanto nos Ambulocetidae, o membro traseiro apresentava os elementos ósseos típicos dos membros de mamíferos. Tratava-se de animais que usavam os meios aquático e terrestre, mas alimentavam-se principalmente no meio aquático, remando com os quatro pés para locomover-se nesse meio.

Na família Remingtonocetidae, acham-se cetáceos fósseis, que são encontrados nos mesmos depósitos fósseis que os Ambulocetidae, mas apresentam maior diversidade em depósitos mais recentes, que datam de 4,8 a 411 milhões de anos atrás (ver a figura 4). Como as famílias anteriores, os Remingtonocetidae parecem ter apresentado pequena distribuição geográfica, sendo conhecidos apenas em registros fósseis da Índia e do Paquistão. Todos os quatro ou cinco gêneros conhecidos nessa família apresentam um longo focinho, que corresponde a quase dois terços do comprimento do crânio. A natureza especializada da dentição desses animais sugere que sua dieta era diferente daquela dos cetáceos anteriores, indicando mais uma mudança ecológica importante no modo de vida dos cetáceos. A anatomia da mandíbula de Remingtonocetus apresenta estruturas que tornam mais eficiente a transmissão subaquática de sons até o ouvido médio, ou seja, esse é um animal que apresenta mais adaptações à vida em ambientes aquáticos do que os cetáceos anteriores. Conforme indica a morfologia dos órgãos sensoriais, a audição devia ser importante para Remingtonocetus, mas não a visão, o que é consistente com evidências geológicas que mostram que esses animais viviam em uma baía cheia de sedimentos trazidos por rios. Esses cetáceos tinham pernas curtas e uma cauda longa e poderosa. Portanto, deveriam usar a cauda como principal meio de propulsão, movendo-se por ondulação caudal, possivelmente sacudindo 


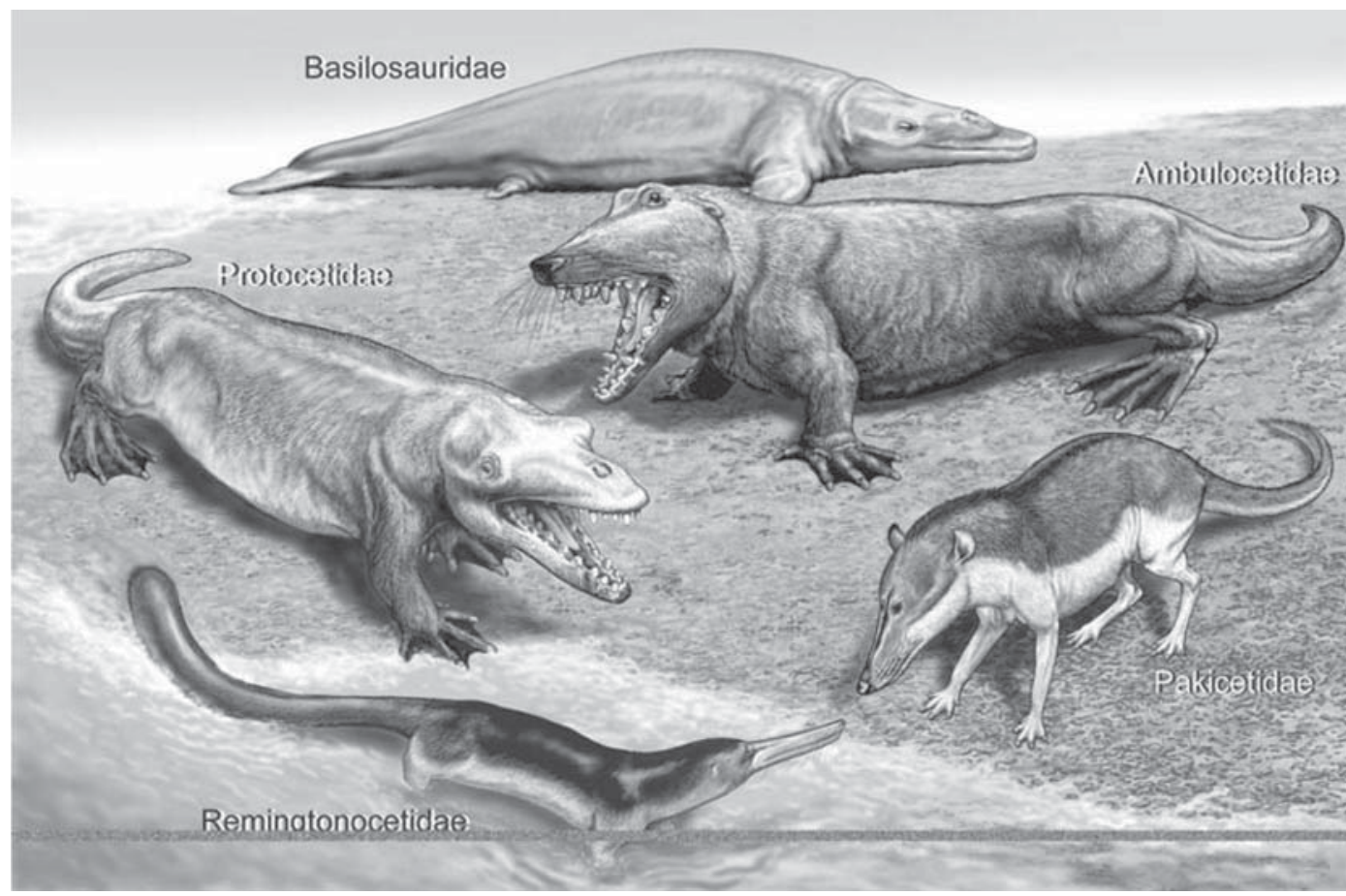

Figura 4. As mudanças no plano corporal dos cetáceos durante os primeiros dez milhões de anos de evolução do clado.

a cauda para cima e para baixo durante o nado. Assim, a seleção natural pôde favorecer um alongamento da cauda, acompanhado por uma redução gradual dos membros posteriores. Os membros dos Remingtonocetus eram provavelmente usados para manobrar na água. Eles deviam ser nadadores rápidos, mas com capacidade limitada de movimentar-se na terra. Os Remingtonocetídeos podem ter sido parecidos com enormes lontras com focinhos compridos (Thewissen et al., 2006; Thewissen et al., 2009).

Essa perspectiva funcional, focada na relação entre a morfologia do membro e o modo de locomoção, é corroborada por dados experimentais que indicam que, como animais que voltaram a um modo de vida aquático, os cetáceos evoluíram na direção de uma forma similar a um torpedo, que é a mais vantajosa em termos hidrodinâmicos. Temos, assim, evidências tanto paleontológicas quanto experimentais de uma redução gradual dos membros posteriores por seleção natural para maior eficiência na natação. Em particular, ao final do Eoceno, a pressão seletiva para a perda dos membros posteriores pode ter sido importante. Até esse ponto, essa é uma narrativa microevolutiva, que trata de mudança gradual no membro traseiro de cetáceos por processos de seleção natural dentro de populações (ver a figura 5 ). 


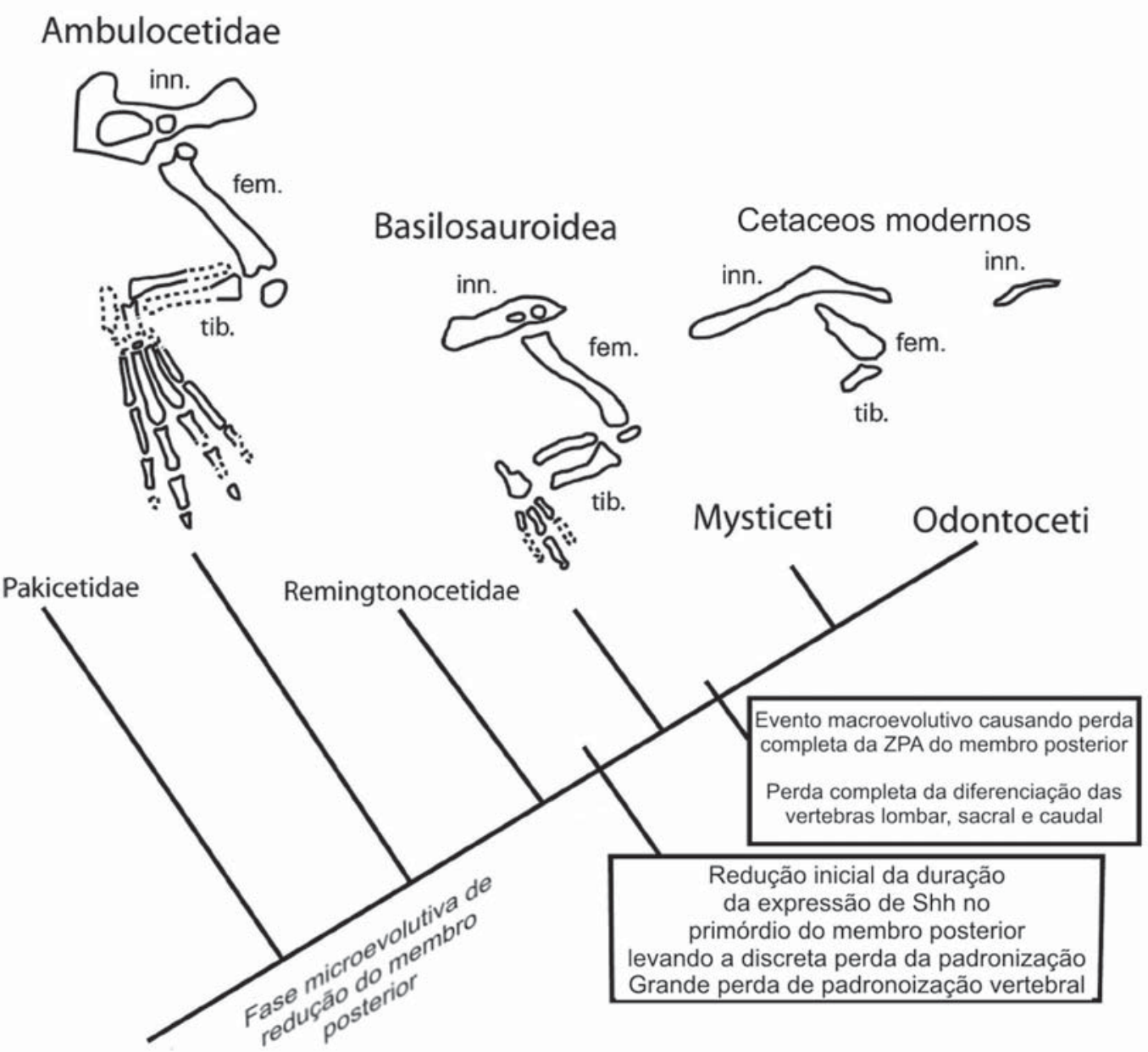

Figura 5. Filogenia simplificada dos cetáceos, mostrando a combinação de um processo microevolutivo de redução dos membros posteriores, por meio da ação da seleção natural, com evento macroevolutivo, relativo à regulação gênica do desenvolvimento, que causou a perda completa desses membros no ancestral comum dos cetáceos modernos (as subordens mysticeti e odontoceti). São mostradas as anatomias dos membros traseiros de um gênero da família ambulocetidae (cujo nome significa "baleia ambulante"), ambulocetus; de um gênero da superfamília basilosauroidea, basilosaurus (esses dois grupos contêm apenas organismos fósseis); e de dois misticetos modernos, a baleia franca boreal (Balaena mysticetus), à esquerda, e a baleia sei (Megaptera borealis), à direita. Na maioria dos odontocetos, o único elemento ósseo preservado no membro traseiro é um dos ossos do quadril (no latim, innominate), como vemos também no caso da baleia sei. Os elementos ósseos do membro traseiro nomeados na figura são innominate (inn.), fềmur (fem.) e tíbia (tib.). 
Os primeiros cetáceos que se espalharam por todo o globo, não permanecendo restritos, como os cetáceos anteriores, às áreas que hoje correspondem à Índia e ao Paquistão, foram os Protocetidae. Esse grupo de cetáceos provavelmente teve uma distribuição global entre 49 e 40 milhões de anos atrás, no Eoceno médio. Trata-se de um grupo diverso, no qual foram descritos cerca de 15 gêneros, que se diferenciavam em muitas características, tais como o comprimento do focinho e a morfologia das orelhas. É difícil avaliar a morfologia do esqueleto pós-cranial e sua variabilidade nos Protocetidae, porque apenas em algumas espécies há restos fósseis desses ossos, principalmente dos Rodhocetus e Artiocetus, encontrados no Paquistão, e dos Georgiacetus, da América do Norte. Nos fósseis escavados no Paquistão, os membros são curtos, as mãos têm cinco dedos, os pés, quatro, e os pés são muito maiores do que as mãos. Eram animais capazes de locomover-se na terra e é provável que utilizassem os ambientes terrestre e marinho de maneira similar aos leões marinhos de hoje, isto é, caçando na água, mas cruzando, parindo e criando seus filhotes na terra. No caso de Georgiacetus, a pélvis parece não estar conectada à coluna vertebral, o que sugere que os membros não poderiam suportar o peso do animal em terra, de modo que pode ter sido um animal mais aquático do que os outros procetídeos. Tem sido geralmente aceito que os protocetídeos não possuíam ainda a nadadeira caudal típica dos cetáceos, combinando em sua natação o uso das pernas traseiras para remar e ondulações dorsoventrais da cauda (Thewissen et al., 2009).

Os Basilosauridae foram os primeiros cetáceos completamente aquáticos, ou seja, que jamais deixavam o oceano (ver a figura 4). Tendo surgido há cerca de 411 milhões de anos, eles são os primeiros animais na história do clado que lembram os cetáceos modernos, sendo bastante diferentes dos protocetídeos. Fósseis de basilossaurídeos foram encontrados em todo o globo, tendo provavelmente vivido em todos os oceanos da Terra entre 41 e 35 milhões de anos atrás. Os basilosaurídeos possuíam uma abertura nasal bastante deslocada para trás, em relação aos cetáceos anteriores, formando um respiradouro; seus membros anteriores já haviam se transformado em nadadeiras; a nadadeira caudal típica dos cetáceos já estava presente; e seus membros traseiros eram muito pequenos, incapazes de suportar o peso do corpo em terra. Os membros traseiros dos basilossaurídeos não somente eram rudimentares, mas também não possuíam todos os ossos tipicamente encontrados em mamíferos tetrápodes (Thewissen et al., 2006). São conhecidos até hoje cerca de sete gêneros de Basilosauridae, que podem ser divididos em dois tipos de planos corporais. O gênero Basilosaurus ilustra o primeiro tipo, um corpo serpentiforme com comprimento máximo de aproximadamente 17 metros. Esses animais podem ter nadado através de movimentos sinuosos de todo o corpo. O segundo tipo, ilustrado pelo gênero Durodon, consiste em um corpo similar ao de um golfinho, com cerca de 4 metros de comprimento. Nesse caso, a natação 
provavelmente ocorria por meio de movimentos dorsoventrais da nadadeira caudal (Thewissen et al., 2009).

Uma importante diferença entre os Protocetidae e Basilosauridae e os cetáceos anteriores reside no fato de que a abertura nasal dos primeiros animais não se encontra na ponta do focinho, mas em posição mais posterior, que é evidentemente transicional em relação à futura posição do respiradouro de baleias e golfinhos modernos, uma importante adaptação para a vida aquática (ver a figura 6). Este é mais um dos aspectos que mostra como a evolução dos cetáceos fornece um excelente cenário narrativo para a compreensão da natureza do processo evolutivo, combinando eventos macroevolutivos (ver abaixo) com mecanismos microevolutivos, que têm como resultado transformações graduais, como as que vemos ao longo da redução inicial dos membros, das mudanças morfológicas da cauda e da posição da abertura nasal de diferentes famílias desse clado. ${ }^{3}$

Por volta de 34 milhões de anos atrás, surgiram os primeiros representantes dos cetáceos modernos, das subordens Odontoceti e Mysticeti, que formam um único grupo monofilético, isto é, compartilham um ancestral comum. A mais importante inovação do plano corporal dos odontocetos foi a aquisição da ecolocação, enquanto em misticetos, a principal inovação foi o surgimento de estruturas que permitem a alimentação por filtração (as barbas, que são longas placas flexíveis de queratina). Ambas as subordens são compostas por grande diversidade de espécies, encontradas em quase todos os oceanos, com distintos modos de alimentação. Os cetáceos atuais locomovemse de modo similar, mostrando uma série de adaptações para o deslocamento na água, como o corpo hidrodinâmico e os membros posteriores geralmente ausentes.

Mas como o membro traseiro dos cetáceos chegou a praticamente desaparecer? Embora pudesse ser plausível um cenário baseado apenas em microevolução, na continuidade evolutiva do processo de seleção para maior eficiência na natação, dados fornecidos pelo estudo do desenvolvimento do golfinho-pintado-tropical (Stenella attenuata) indicaram outro cenário. Thewissen e colaboradores (2006) esclareceram as alterações na regulação do desenvolvimento que resultaram na redução muito acentuada dos membros traseiros, como vemos nos cetáceos modernos. A partir do estudo do papel de genes como Sonic hedgehog (Shh), que codifica uma molécula de sinalização celular, e Hand2, que codifica um fator de transcrição, esses autores mostraram que é a falta de ativação de Shh por Hand2 que resulta na inibição do desenvolvimento do membro posterior.

3 Não é por acaso que a evolução dos cetáceos figura, lado a lado com vários outros casos, em excelente número especial de 2009 do periódico Evolution: Education and Outreach, que mostra como não há falta de casos bem documentados de fósseis transicionais no conhecimento evolutivo atual, diferentemente do que se argumenta, de maneira equivocada, em alguns textos criacionistas. 

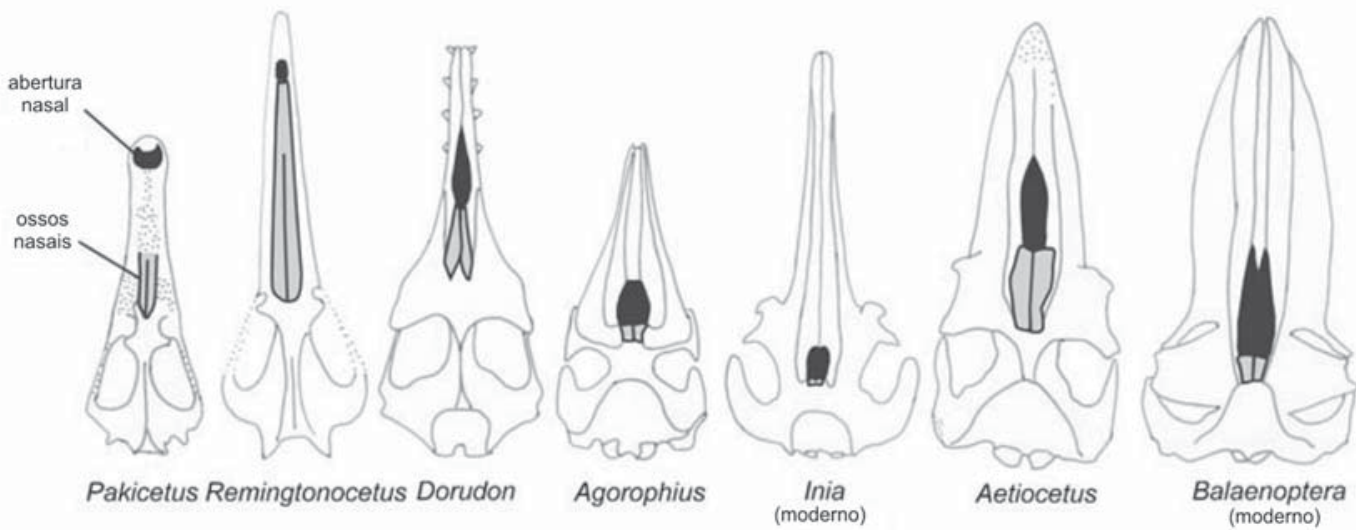

Figura 6. Mudança gradual da posição da abertura nasal nos cetáceos. Os primeiros cetáceos tinham ossos nasais (em cinza) e abertura nasal (em preto) próximos à extremidade do focinho. À medida que esses animais foram tornando-se mais aquáticos, a seleção natural favoreceu organismos com ossos nasais retraídos e abertura nasal localizada mais perto do topo do crânio, o que terminaria por dar origem ao respiradouro dos cetáceos modernos.

Embora os cetáceos atuais não possuam membros traseiros, seus embriões iniciam o desenvolvimento do broto desses membros. Contudo, por volta da quinta semana de gestação, o broto interrompe seu desenvolvimento e degenera nos golfinhos. Para entender por que isso acontece, devemos considerar que o crescimento inicial dos membros dos amniotas é mantido por dois centros de sinalização celular, a crista ectodérmica apical (AER, do inglês apical ectodermal ridge) e a zona de atividade polarizadora (ZPA, do inglês zone of polarizing activity). Essas são regiões do membro em desenvolvimento que secretam moléculas de sinalização celular diferentes, que se difundem pelos tecidos em formação no membro, estabelecendo comunicação entre as células e, assim, regulando os processos de morfogênese. Para nossos propósitos aqui, interessa sobretudo a ZPA, que secreta a molécula Shh.

$\mathrm{O}$ broto do membro traseiro do golfinho $\mathrm{S}$. attenuata estabelece o centro de sinalização celular AER, mas esse centro não é mantido, sendo esta a razão pela qual o membro interrompe seu desenvolvimento na quinta semana de gestação. É preciso considerar, então, que a manutenção da AER requer sinalização celular pela ZPA. Thewissen e colaboradores (2006) mostraram que a perda dos membros traseiros no golfinho $S$. attenuata está relacionada a um defeito na sinalização pela ZPA. Shh é expressa nos membros dianteiros de embriões de $S$. attenuata, mas não nos membros traseiros. A ausência de expressão de Shh, ou seja, uma falha no estabelecimento da ZPA, acarreta o desaparecimento da AER e, logo, a interrupção do desenvolvimento do 
membro. Como a expressão de Shh, por sua vez, depende da ativação do gene correspondente por Hand2, os autores conseguiram mostrar que é na falha da ativação do gene Shh por esse fator de transcrição que a cascata de regulação gênica do desenvolvimento do membro é interrompida.

O próximo passo, então, é situar esses mecanismos desenvolvimentais na história evolutiva, na filogenia dos cetáceos, tal como fizemos com os processos de seleção natural que levaram à redução gradual dos membros posteriores por microevolução. O mecanismo envolvendo perda de expressão de Shh foi responsável pela ausência de membros traseiros no último ancestral comum dos cetáceos modernos, mas, como vimos, o cenário evolutivo em questão é mais complexo: a perda macroevolutiva de Shh e da ZPA é um evento tardio em um processo de redução e perda de função locomotora do membro traseiro que já vinha ocorrendo (ver a figura 5 ).

Thewissen e colaboradores (2006) argumentam que a perda de elementos distais dos membros traseiros de basilossauróides (um osso metatarsal e várias falanges) deve ter resultado de uma redução da duração da expressão de Shh há cerca de 411 milhões de anos, o que indicaria que a regulação da expressão desse gene por Hand2 já poderia ter começado a falhar. A perda adicional de elementos dos membros traseiros próxima à origem das subordens modernas de cetáceos, há cerca de 34 milhões de anos, teria decorrido, então, da perda completa da expressão de Shh e, portanto, da ZPA.

O principal ponto a ressaltar no exemplo reside no fato de que ele combina em uma narrativa evolutiva bela e instigante - e, além disso, potencialmente útil no ensino da evolução - processos microevolutivos relativos à seleção natural e macroevolutivos relativos a alterações na regulação de processos do desenvolvimento, tal como argumentamos acima. Ou seja, em contraste as com explicações da evolução de traços que recorrem a apenas um agente causal (em geral, a seleção natural), temos um exemplo bastante claro do que chamamos aqui de pluralismo de processos.

O exemplo permite ilustrar, portanto, como o pensamento evolutivo atual se vale - e, mais do que isso, deve valer-se - de uma variedade de tipos de agentes causais para explicar a evolução biológica. O argumento se sustenta não pelo fato de que os avanços da biologia evolutiva do desenvolvimento são capazes de gerar, atualmente, dados interessantes sobre a produção da forma orgânica, mas por algo mais forte, a saber, a evidência de que, em muitos casos, o entendimento dos processos que subjazem às modificações da forma são peças fundamentais nas explicações evolutivas.

Por fim, devemos reiterar que não podemos perder de vista que existem tanto aspectos do processo evolutivo que são melhor explicados por meio da seleção natural, como a origem das adaptações, quanto aspectos que são melhor compreendidos se considerarmos os mecanismos desenvolvimentais que resultam na modificação da forma orgânica, como os casos de homeose (cf. Wagner, 2000). Além disso, como bem ilustra 
a evolução do plano corporal dos cetáceos, frequentemente necessitaremos de ambos os componentes explicativos. Não se trata, então, de propor a hegemonia de uma explicação sobre a outra, seja a formal (estruturalista), seja a funcional (selecionista). Acreditamos que o melhor caminho seja considerar modelos evolutivos diversos, cenários nos quais contemplemos sempre a possibilidade da ação de diferentes mecanismos causais no processo evolutivo, prestando atenção ainda na importância relativa distinta que cada mecanismo pode ter em cada narrativa evolutiva.

\section{Considerações FINAIS}

Afirmamos acima que a evo-devo pode contribuir para a compatibilização de perspectivas estruturalistas e funcionalistas nas explicações científicas do processo evolutivo. Portanto, é importante avaliar em que medida esse campo não representa somente um retorno a perspectivas estruturalistas e transformacionais anteriores. Nossa estratégia para fazer tal avaliação foi retomar algumas ideias sobre a natureza do pensamento darwinista sobre a evolução de que tratamos acima, examinando em que medida a evodevo é consistente com essas ideias.

Entre os legados dos trabalhos de Darwin para o pensamento evolutivo, destacamos, primeiro, a sustentação da ideia de evolução com base em grande quantidade e diversidade de evidências. É óbvio que a evo-devo não só é consistente como reforça nossa compreensão da evolução, não se comprometendo com ideias que se opõem ao modo como temos pensado a evolução desde Darwin, como, por exemplo, o design inteligente (apesar de alguns sítios dedicados a este último apropriarem-se, em nosso entendimento, de modo inteiramente equivocado e indevido de achados da evo-devo). Ela tampouco coloca em xeque a tese de que todos os seres vivos são aparentados entre si.

A seleção natural constitui, claro, outra contribuição de Darwin que permanece central na biologia evolutiva até os dias de hoje. Como o exemplo da evolução do plano corporal dos cetáceos ilustra, ter na devida conta as alterações oriundas da regulação do desenvolvimento embrionário, investigadas de modo comparativo pela evo-devo, não priva de poder causal e explicativo a seleção natural. Não se trata, portanto, de propor algum tipo de visão antidarwinista.

Contudo, é correto afirmar que, bem de acordo com uma visão pluralista sobre o processo evolutivo, a seleção natural perde parte de seu poder explicativo e causal para outros mecanismos, quando consideramos a origem das inovações morfológicas por meio do desenvolvimento, as possibilidades e as restrições que este último processo produz, bem como a deriva gênica, a auto-organização e outros processos que não consideramos no presente artigo. Contudo, uma negação de seu poder explicativo e causal 
não se segue de um reconhecimento de limites da seleção natural como mecanismo explicativo. A seleção natural é, por exemplo, o mecanismo que explica a origem das adaptações. Isso segue, aliás, de uma compreensão da adaptação atualmente muito influente, de acordo com a qual um traço é uma adaptação para alguma tarefa caso tenha se tornado prevalente em uma população porque houve seleção para aquela tarefa que ele realiza (Sober, 1993, p. 208). Dessa perspectiva, a seleção natural explica toda e qualquer adaptação, porque, para ser uma adaptação, um traço deve ter se tornado prevalente em uma população devido à seleção natural (Sepúlveda \& El-Hani, 2008). A questão, então, é que nem todos os traços dos organismos são adaptações e há outros fenômenos evolutivos a explicar além da origem de adaptações, como, por exemplo, a especiação ou a extinção. Em boa medida (ainda que não inteiramente), os limites explicativos da seleção coincidem com os limites das adaptações como objetos de explicação no mundo vivo. Portanto, os limites da seleção natural são também os do adaptacionismo (Rosenberg \& McShea, 2008).

A perda de poder da seleção natural como causa e explicação da evolução não deve produzir espanto, na medida em que o compromisso com uma visão pluralista necessariamente se afasta de uma visão adaptacionista na qual a seleção seja vista como mecanismo que explica toda a evolução. ${ }^{4}$ Se um mecanismo, que antes se considerava explicar tudo, passa a ser combinado com outros mecanismos, naturalmente ele deverá perder parte de seu poder explicativo. Mas nunca é demais repetir, dados os frequentes equívocos a esse respeito: isso não implica que estaríamos em trânsito para uma visão sobre a evolução contrária ao darwinismo, e sim - como argumenta Gould (2002), em nosso parecer, com sucesso - para uma nova visão darwinista.

Outra ideia central do darwinismo ao longo de sua história é a de ancestralidade comum e, consequentemente, da evolução como um processo aberto, contingente, sem meta definida, tal como representado em uma árvore evolutiva. Mais uma vez, basta examinar a narrativa evolutiva sobre os cetáceos discutida acima para ver que não há qualquer incompatibilidade com essa visão darwinista da evolução. O retorno ao estruturalismo que podemos identificar na evo-devo não implica compromisso com modelos evolutivos que enfatizem tendências lineares de transformação.

Em relação a debates contemporâneos importantes, a evo-devo favorece a ideia de que nem todas as mudanças macroevolutivas podem ser explicadas por processos microevolutivos graduais, de seleção natural dentro de populações. As alterações na

4. De fato, esse tipo de visão adaptacionista é, obviamente, incompatível com o pluralismo de processos. Contudo, a partir de uma distinção entre variedades de adaptacionismo, é possível identificar certas visões defendidas por autores tidos como adaptacionistas que podem ser reconciliadas com o pluralismo. Para maiores detalhes, cf. GodfreySmith (2001), Andrews, Gangestad \& Matthews (2002), Sepulveda \& El-Hani (2008), Sepulveda et al. (no prelo). 
regulação do desenvolvimento tornam possível, como discutimos acima, mudanças evolutivas em taxas mais rápidas, como nos casos de homeose.

Por fim, a principal contribuição da evo-devo ao pensamento evolutivo moderno reside na compreensão dos agentes causais responsáveis pela modificação da forma orgânica em um panorama que continua sendo darwinista, comprometido com o pensamento variacional/populacional, e não transformacional. Ao mostrar que as inovações morfológicas podem ser mais bem compreendidas, quando entendemos modificações na regulação do desenvolvimento dos organismos, sem perder de vista o papel da seleção natural na triagem dessas inovações, a evo-devo nuança a dicotomia entre estruturalismo e funcionalismo, tornando possível uma síntese entre forma e função na compreensão do processo evolutivo.

Embora o foco do presente artigo recaia sobre uma apreciação de como as visões estruturalistas e funcionalistas podem ser compatibilizadas no contexto de uma teoria variacional da evolução, a partir das contribuições oriundas da evo-devo, não podemos deixar de mencionar que abordagens que enfoquem a origem das formas orgânicas, tal como vemos no caso da evolução dos cetáceos, são necessárias no ensino médio da evolução. Afinal, a maioria dos estudantes quer saber qual a resposta a perguntas como "de onde vieram as baleias e os golfinhos?", "como é possível que a seleção os tenha produzido?", e não apenas aprender o que supostamente diferenciaria as ideias de Lamarck e Darwin, e como funciona a seleção natural. Não obstante a importância de abordar a história do pensamento evolutivo (em particular, se as narrativas anacrônicas e incorretas que abundam no ensino da biologia forem superadas) e de dar aos estudantes acesso à compreensão da teoria da seleção natural, é preciso ir além disso. A recontextualização didática das narrativas evolutivas, como a da origem do plano corporal dos cetáceos, lado a lado com os mecanismos evolutivos, cria condições, em nossa visão, para um ensino da evolução muito mais efetivo.

Agradegimentos. Ana Maria Rocha de Almeida agradece à FAPESB pela bolsa de pesquisa (AT-2) concedida durante o ano 2007-2008 e à CAPES/Fullbright pela bolsa de doutorado pleno no exterior concedida a partir de 2009. Charbel Niño El-Hani agradece ao CNPq, à FAPESB e à FINEP pelo financiamento de projetos de pesquisa e ao CNPq por bolsa de produtividade em pesquisa. 


\title{
Ana Maria Rogha de Almeida
}

Doutoranda do Programa de Pós-graduação em Plant Biology,

University of California, Berkeley, EUA.

Bolsista de doutorado pleno no exterior CAPES/Fulbright, Brasil/EUA. ana_almeida@berkeley.edu

\author{
Charbel Niño EL-HANI \\ Professor Doutor do Departamento de Biologia Geral, \\ Instituto de Biologia,Universidade Federal da Bahia. \\ Pesquisador do Conselho Nacional de Pesquisa Científica, \\ CNPq, Brasil. \\ charbel.elhani@pesquisador.cnpq.br
}

\begin{abstract}
Development has a central role in the understanding of the evolution of multi-cellular organisms mainly because it is the process that results in the adult organic form. Therefore, every morphological innovation is also a result of changes in development. However, developmental biology remained at the margin of the modern evolutionary synthesis and development has been treated for a long time as a black-box between genotype and phenotype. Only at the beginning of 1980 s, the role of development received more attention, and this resulted in unexpected empirical and theoretical progress. This progress resulted in the emergence of a new research field, evolutionary developmental biology (evo-devo), which has been playing an important role in the construction of a new understanding of the evolution of organic forms. We argue that this field has a central role in a "new evolutionary synthesis", currently under construction, which is committed to a "pluralism of processes", that is, the idea that not only natural selection but also a variety of different mechanisms play causal and explanatory roles in biological evolution. We discuss some classical dichotomies in evolutionary thought, particularly between structuralism and functionalism, and transformational and variational processes, in an effort to situate evo-devo in contemporary evolutionary thought.
\end{abstract}

KeYwords • Evolutionary developmental biology. Evo-devo. Form. Function. Structuralism. Functionalism. Transformationism. Variationism.

\section{REFERÊNGIAS BIBLIOGRÁFICAS}

Abrantes, P. (Org.). Filosofia da biologia. Porto Alegre: Artmed. No prelo.

Amundson, R. Historical development of the concept of adaptation. In: Rose, M. R. \& Lauder, G. V. (Ed.). Adaptation. San Diego: Academic Press, 1996. p. 11-53.

Amundson, R. The changing role of the embryo in evolutionary thought: roots of evo-devo. Cambridge: Cambridge University Press, 2005.

Andrews, P. W.; Gangestad, S.W. \& Matthews, D. Adaptationism - how to carry out an exaptationist program. Behavioral and Brain Sciences, 25, p. 489-553, 2002. 
Автнur, W. The origin of animal body plans. Cambridge: Cambridge University Press, 1997.

. The emerging conceptual framework of evolutionary developmental biology. Nature, 415, p. 757-

$64,2002$.

Bateson, W. Materials for the study of variation. London: Macmillan, 1894.

BowLER, P. El eclipse del darwinismo. Barcelona: Labor, 1983.

. Evolution: the history of an idea. 3. ed. Berkeley: University of California Press, 2003.

Bridges, C. B. \& Morgan, T. H. The third-chromosome group of mutant characters of Drosophila melanogaster. Baltimore: The Lord Baltimore Press, 1923. (Carnegie Institution of Washington, Publication Nb. 327).

CaIn, J. \& Ruse, M. (Ed.). Descended from Darwin: insights into the history of evolutionary studies, 1900-1970. Philadelphia: American Philosophical Society, 2009.

Caponi, G. O darwinismo e seu outro, a teoria transformacional da evolução. Scientiae Studia , 3, 2, p. 23342,2005 .

. El vivente y su medio: antes y después de Darwin. Scientiae Studia , 4, 1, p. 9-4,3, 2006.

. La filosofía de la biología y el futuro de la biología evolucionaria. Ludus Vitalis, 15, 28, p. 199-202, 2007 .

CARroll, S. Infinitas formas de grande beleza. Rio de Janeiro: Jorge Zahar, 2006.

Carroll, S; Grenier, J. K. \& Weatherbee, S. D. From DNA to diversity: moleculargenetics and the evolution of animal design. Oxford: Blackwell, 2005.

DARWIN, C. R. On the origin of species by means of natural selection, or preservation of favored races in the struggle for life. London: Murray, 1859.

Doolittle, W. F. \& Bapteste, E. Pattern pluralism and the tree of life hypothesis. Proceedings of the National Academy of Sciences, 104, p. 204,3-9, 2007.

Edelman, G. Topobiology: an introduction to molecular embryology. New York: Basic Books, 1988.

EL-Hani, C. N. \& Videira, A. A. P. (Org.). O que évida? Para entender a biologia do século XXI. Rio de Janeiro: Relume Dumará, 2000.

ELENA, S. F. \& LeNsKy, R. E. Evolutionary experiments with microorganisms: the dynamics and genetic bases of adaptations. Nature Reviews Genetics, 4, p. 457-69, 2003.

GARDNER, J. et al. Story-telling: an essential part of science. Trends in Ecology and Evolution, 22, 10, p. 510, 2006.

Gavin, A. C. et al. Functional organization of the yeast proteome by systematic analysis of protein complexes. Nature, 415, p. 141-7, 2002.

Godfrey-Smith, P. Three kinds of adaptationism. In: Orzack, S. H. \& Sober, E. (Ed.). Adaptationism and optimality. Cambridge: Cambridge University Press, 2001. p. 335-57.

Goldschmidt, R. The material basis of evolution. New Haven: Yale University Press, 194,O.

Gould, S. J. Ontogeny and phylogeny. Cambridge: Harvard University Press, 1977.

. The structure of evolutionary theory. Cambridge: Harvard University Press, 2002.

Gould, S. J. \& Lewontin, R. C. The spandrels of San Marco and the panglossian paradigm: a critique of the adaptationist programme. Proceedings of The Royal Society of London, 205, p. 581-98, 1979.

Grant, P. R. \& Grant, B. R. Predicting microevolutionary response to directional selection on heritable variation. Evolution, 49, p. 242-51, 1995 .

\& __. Unpredictable evolution in a 30-year study of Darwin finches. Science, 296, p. 707-11, 2002.

Hendry, A. P. \& Kinnison, M. T. An introduction to microevolution: rate, pattern, process. Genetica, 1123, p. 1-8, 2001 .

Hull, D. Recent philosophy of biology: a review. Acta Biotheoretica, 5०, p. 117-28, 2002.

ЈАСов, F. Evolution and tinkering. Science, 196, p. 1161-6, 1977 .

Konnblintт, A. R. et al. Multiple links between transcription and splicing. $R N A$, 10, p. 14.89-98, 2004 . 
Largent, M. A. The so-called eclipse of Darwinism. In: Cain, J. \& Ruse, M. (Ed.). Descended from Darwin: insights into the history of evolutionary studies, 1900-1970. Philadelphia: American Philosophical Society, 2009. p. 3-21.

Laubichler, M. D. \& Maienschein, J. (Ed.). From embryology to evo-devo: a history of developmental evolution. Cambridge: MIT Press, 2007 .

MANiAtis, T. \& REed, R. An extensive network of coupling among gene expression machines. Nature, ${ }_{1} 16$, p. 499-506, 2002.

MaYr, E. O desenvolvimento do pensamento biológico. Brasília: UnB, 1998 [1982].

MaYr, E. \& Provine, W. The evolutionary synthesis. Cambridge: Harvard University Press, 1980.

McGinnis, W. et al. A homologous protein-coding sequence in Drosophila homeotic genes and its conservation in other metazoans. Cell, 37, p. 4,०3-8, 1984 .

Meyer, D. \& El-Hani, C. N. Evolução. In: El-Hani, C. N. \& Videira, A. A. P. (Org.). O que é vida? Para entender a biologia do século XXI. Rio de Janeiro: Relume Dumará, 2000. p. 153-85.

\& __ . Evolução: o sentido da biologia. São Paulo: Editora Unesp, 2005.

$\mathrm{OH}$, B. et al. Timely translation during the mouse oocyte-to-embryo transition. Development, 127, p. 3795803,2000

Orzack, S. H. \& Soвer, E. (Ed.).Adaptationism and optimality. Cambridge: Cambridge University Press, 2001.

Ospovat, D. The development of Darwin's theory. Cambridge: Cambridge University Press, 1981.

RAFF, R. The shape of life: genes, development, and the evolution of animal form. Chicago: The University of Chicago Press, 1996.

Reznick, D. N. \& EndLer, J. A. The impact of predation on life-history evolution in Trinidadian guppies (Poecilia reticulata). Evolution, 36, p. 160-77, 1982.

Reznick, D. N. \& Ghalambor, C. The population ecology of contemporary adaptation: what empirical studies reveal about the conditions that promote adaptive evolution. Genetica, 112-3, p. 183-98, 2001.

Reznick, D. N.; Bryga, H. \& Endler, J. A. Experimentally induced life-history evolution in a natural population. Nature, 346 , p. $357^{-}$9, 1990.

Rose, M. R. \& Lauder, G. V. (Ed.).Adaptation. San Diego: Academic Press, 1996.

Rosenberg, A. \& McShea, D. W. Philosophy of biology: a contemporary introduction. New York: Routledge, 2008.

Sam Pedro, J. Deconstruyendo a Darwin. Barcelona: Crítica, 2002.

SANTos, F. \& DeAn, W. Epigenetic reprogramming during early development in mammals. Reproduction, 127, p. $643-3^{1}, 2004$.

Schier, A. F. The maternal-zygotic transition: death and birth of RNAs. Science, 316, p. 4.06-7, 2007.

Schultz, R. M. Regulation of zygotic gene activation in the mouse. Bioessays, $15,8, \mathrm{p} .5^{31-8}$.

Scott, M. P. \& Weiner, A. J. Structural relationships among genes that control development: sequence homology between the Antennapedia, Ultrabithorax and fushi tarazu loci of Drosophila. Proceedings of the National Academy of Sciences, 81, p. 4115-9, 1984.

Sepulveda, C. \& El-Hani, C. N. Adaptacionismo versus exaptacionismo: o que este debate tem a dizer ao ensino de evolução? Ciência e Ambiente, 36, p. 93-124, 2008.

Sepulveda, G.; Meyer, D. \& El-Hani, C. N. Adaptacionismo. In: Abrantes, P. (Org.). Filosofia da biologia . Porto Alegre: Artmed. No prelo.

SoвеR, E. The nature of selection: evolutionary theory in philosophical focus. Chicago: The University of Chicago Press, 1993.

Thewissen, J. G. M. \& Fish, F. E. Locomotor evolution in the earliest cetaceans: functional model, modern analogues, and paleontological evidence. Paleobiology, 23, p. 482-90, 1997. 
Thewissen, J. G. M. et al. Developmental basis for hind-limb loss in dolphins and the origin of the cetacean bodyplan. Proceedings of the National Academy of Science, 103, p. 84,14,-8, 2006.

. Whales originated from aquatic artiodactyls in the Eocene epoch of India. Nature, 450, p. 1190-5, 2007 .

From land to water: the origin of whales, dolphins, and porpoises. Evolution: Education, and Outreach, 2, p. 272-88, 2009 .

WAgner, G. What is the promise of developmental evolution? Part 1: why is developmental biology necessary to explain evolutionary innovations. Journal of Experimental Zoology, 288, p. 95-8, 2000.

. The current state and the future of developmental evolution. In: Laubichler, M. D. \& Maienschein, J. (Ed.). From embryology to evo-devo: a history of developmental evolution. Cambridge: MIT Press, 2007. p. 525-45

Wassarman, P. M. et al. Protein synthesis during meiotic maturation of mouse oocytes in vitro. Synthesis and phosphorylation of a protein localized in the germinal vesicle. Developmental Biology, 69, 1, p. 94,-107, 1979.

Weismann, A. The germ plasm: a theory of heredity. London: Walter Scott, 1983 [1893].

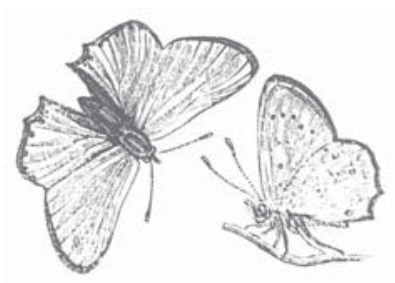

